\title{
Role of Government in Keeping Price Stability Through Pure Market Operation From an Islamic Economic Perspective
}

\author{
Soya Sobaya \\ Department of Islamic Economics, \\ Faculty of Islamic Studies \\ Universitas Islam Indonesia \\ Jakarta, Indonesia \\ soya.sobaya@uii.ac.id
}

\author{
Zakka Hifzhan Hanifan Fadhlulloh \\ Department of Islamic Economics, \\ Faculty of Islamic Studies \\ Universitas Islam Indonesia \\ Jakarta, Indonesia \\ 14423202@students.uii.ac.id
}

\author{
Yuli Andriansyah \\ Department of Islamic Economics, \\ Faculty of Islamic Studies \\ Universitas Islam Indonesia \\ Jakarta, Indonesia \\ yuliandriansyah@uii.ac.id
}

\begin{abstract}
This research analyzed the Pure Market Operation program carried out by the government in the light of Islamic economic perspective. Qualitative research was used as the main design of this research to obtain an over-view of the work of the Pure Market Operation implemented by the government and supported by quantitative research that was used as a supporting design by taking 30 respondents using purposive sample method. Samples are those who have participated in the Pure Market Operation activities conducted by the government to find out the benefits of the program. The research results show that the Pure Market Operation program carried out by the government in accordance with the objectives of Islamic economics and is good for the society.
\end{abstract}

Keywords: Islamic economics, Pure Market Operation, price stability, role of government

\section{INTRODUCTION}

The growth of a capital mobility from a country is something that cannot be denied from trade liberalization which on one hand has also created several inequalities in terms of the country's economy. On the other hand, Islam raises the concept of the role of a country in the economic field on the basis of universal Islam such as the existence of justice in terms of the economy from the redistribution of in-come, either through zakat or social security or the prohibition of usury [1].

Ibnu Khaldun analyzed that the weakness and strength of the role of government depends on its commitment to creating justice and public welfare [2]. Without justice, community loyalty will not exist; if there is no loyalty, there will be no environment that supports the implementation of Sharia, law and legislation, develPure Market Operation ent and prosperity. This absence will cause political administration and government to be weak and ineffective, which if left unchecked will lead to destruction.

Various programs are implemented by the government to stabilize the prices of commodity goods, one of which is by Pure Market Operation (operasi pasar murni in Bahasa Indonesia). Pure Market Operation is an activity carried out by the government or cooperation between the government and good distributors and food companies to avoid an increase in the price of an item, which is done by injection or subsidy, to increase supply through private traders, state-owned enterprises, or directly to retail traders at a time when prices are rising or with cheap market operations [3].
Not only maintaining price stabilization, Pure Market Operation also aims to maintain the supply of commodity goods in every market in the event of price movements, such as inflation or major holidays in Indonesia which causes prices to rise rap-idly in every market. In addition, the Pure Market Operation also aims to ease the burden of people living below the standard of feasibility, be-cause the Market Operation sells commodity goods that are subsidized by the government so that the prices of these goods are below the existing market price. Community needs for ever-changing food prices and forms of programs carried out by the government to stabilize the prices of commodity goods through Pure Market Operation.

\section{LITERATURE REVIEW}

Wulandari [4] showed that inflation has an influ-ence in increasing the potential for poverty in Indo-nesia so that the role of government and government policies is needed to reduce the inflation rate. Kurniawan [5] discussed the suitability of market operations in Islamic law reviews using descriptive analytical research method, that was by describing Ibnu Qayyim's thoughts. Then these thoughts are an-alyzed using a normative approach. The research re-sults indicated that the government has the right to set price of market regulation, especially if there is an injustice and stockpiling. Market operations are in accordance with the rules of Islamic law because they contain beneficial elements.

Susilo [6] discussed the impact of modern market operations on traditional market trade in Pekalongan using descriptive analysis methods and normative testing. The conclusion of this research is that the modern market operations carried out in Pekalongan turned out to only have an impact of $26 \%$ on traditional market traders. Kusumaningrum et al. [7] discussed how the impact of the price of demand and supply of rice prices in Indonesia. This research used data and data source methods (time series) and stage least square estimation. The research result was that the factors that influence rice supply prices are rice production in Indonesia, the amount of rice for seeds, end of year rice stocks. While the demand for rice is influenced by the price of retail rice, the population in Indonesia, the income of the Indonesian population. A $15 \%$ price increase will have an impact on increasing rice production.

Maisyaroh et al. [3] discussed the operation of cheap cooking oil markets to help stabilize prices and avail-ability in 
the Surakarta society. The method used was the center of gravity method. The results showed that cheap market operations can only be used to complete short-term period. Cheap Market Operations in Surakarta are disbursed by the government in the amount of 4,913.05 kg of bulk oil sold for Rp. $10,500 / \mathrm{kg}$. It aimed to avoid a surge in oil prices in Surakarta.

Tatuh et al. [8] discussed the management carried out by PT Semarak in the supply of rice for the people of Bitung City. The method used in this research was the method of economic order quantity (EOQ). The results of the reseach were company policies. The management of Semarak company in managing rice supplies was still not efficient and the orders were not yet economical. Zulham \& Ferizal [9] discussed government intervention in maintaining rice price stabilization in NAD. The method used in this re-search was secondary and primary data methods. Secondary data was obtained from the Office of Agriculture for Food Crops and Horticulture, Public Corporation of National Logistics Agency in Aceh. The primary data was obtained through a survey with the "snow ball" technique traced from farmers, traders, rice milling companies, and etc. The results of the study were that the rice market operation poli-cies carried out by the State Logistics Agency (Perog Bulog Divre) of NAD has not been efficient in re-ducing rice prices at the consumer level

Rahmasuciana et al. [10] discussed the influence of market operations on the procurement of domestic rice. The method used in this research was descriptive analysis method to investigate the rela-tionship between one factor and another which was presented systematically, accurately and factually. The results of the research were that Pure Market Operation had a positive effect on rice price stabilization but was weak. The availability of rice was also influenced by harvested land area and price disparity.

\section{METHODS}

This research used qualitative methods with the ob-ject of research, was the Head of Internal Affairs of DIY DISPERINDAG and Section of Distribution and Procurement of Goods in the Internal Affairs of DISPERINDAG DIY and supported by quantitative methods by purposive sampling on research objects, the community who were beneficiaries of the Pure Market Operation conducted by DISPERINDAG DIY located at Kedung Keris Village, Nglipar District, Gunung Kidul Regency, DI Yogyakarta. The samples were 30 out of 150 beneficiaries who had participated in Pure Market Operation.

\section{RESULTS AND DISCUSSIONS}

From the results of the research analysis data, it can be explained that the discussion on the role of the government in the supply of commodity goods through Pure Market Operation with the results of the characteristics of DISPERINDAG DI Yogyakarta Pure Market Operation beneficiaries is as follow:

\section{A. The role of the government that oversees the main factors of economic drivers}

The role of the government in maintaining price stabilization for the society is through various policy programs, one of which is by means of Pure Market Operation . This is one of the ways to create the good of society. This is in accordance with the Hisbah Region. In Hisbah region, the context of mualamah is all forms of rules that regulate relations between good humans such as: buying and selling, syirkah and others. In this matter the authority of the Hisbah region includes, among other things, prohibiting and supervising forms of fraud such as reducing size and scales, and all forms of practices that contain elements that are not in accordance with morals [11-12].

This was supported by the results of data from community respondents who had received the benefits of Pure Market Operation s conducted by DISPERINDAG DIY. $100 \%$ or 30 people from 30 communities who had participated in the Pure Market Operation activities from the government were aware of the Pure Market Operation activities. Supported by the results of the respondents' data, of the 30 people, there were 28 people or $93.33 \%$ of the people knew that the Pure Market Operation s was one of the policies of the government. 2 out of 30 people or $6.66 \%$ did not know that Pure Market Operation was one of the government's policies.

In the time of the Prophet Muhammad, the practice of hisbah also included the policy of the Prophet Muhammad to reduce fraudulent practices in the market. For example, when Rasulullah PBUH walked to Madinah Market, he met a food seller, then he put his hand in a bag containing wheat and found that the wheat was still wet. Then Rasulullah PBUH said: "That whoever deceives his people is not including his people". In terms of its application, DISPERINDAG DIY is in accordance with the role of government in the economic field of Islamic views that is being a supervisor of the main factors driving the economy of society [1].

\section{B. The role of the government to stop forbidden muamalah}

Pure Market Operation s conducted by DIS-PERINDAG DIY is one of the activities to anticipate inflation and all forms of fraud in prices such as stockpiling. With the existence of Pure Market Operation s, the needs of the community especially those who are less able can be fulfilled. This finding is in line with other research that shows the form of exchange and distribution of goods entering the market and then distributed back to the people in need [13].

Stopping forbidden Muamalah is the aim of implementing the Pure Market Operation on rice and other commodities. A good Pure Market Operation creates a well-functioning society. Holy Quran Surah Al Muthaffifin verses 1-3 explained that a punishment from Allah would occur for those who cheat in economic transaction. The verses explained that committing fraud both in price and stockpiling was forbidden by sharia because it harm another and indirectly decrease community welfare.

\section{The role of the government for price fixing}

The Pure Market Operation conducted by DISPERINDAG DIY is an application of price fixing by subsidies. The subsidized goods are distributed through the Pure Market Operation so that the members of society participates in the program, especially those who live under poverty, could enjoy the benefits of program by receiving cheaper and affordable price. The role of the government in terms of the economy, related to price fixing. Price fixing carried out by the government can create justice and price stabilization due to inflation, price fraud etc [1]. This is also in 
accordance with Al-Qaradhawi's view that there is a need for price fixing to create justice and stability [14].

\section{The role of the government in allocation}

The government as an economic actor has an alloca-tion function. Allocation is an important function in creating price stabilization because the absence of good allocation can create market failures. The Pure Market Operation activity carried out by DISPERINDAG DIY has an allocation of items with a predetermined number of between 150-200 packages. This was supported by the results of data from community respondents who had received the benefits of Pure Market Operation $\mathrm{s}$ conduct-ed by DISPERINDAG DIY regarding the allocation of goods, which was $76.66 \%$ or 23 out of 30 respondents who knew that the amount allocated by the government could meetd the needs of society to cope with rising prices of goods.

This finding is in line with Sumarni's [13] that the Pure Market Operation can be associated with the role of government in the economy. One of it is allocation, which involves procurement of goods such as road construction, telephone net-works. Whereas the allocation that is in accordance with the Pure Market Operation is the allocation of goods to be distributed which can benefit the society.

\section{E. The role of the government in distribution}

Distribution is the main principle in accordance with the intent and purpose to make it easier to obtain goods when needed. Pure Market Operation conducted by DISPERINDAG DIY in terms of distribution accuracy has a target, that is for people living below the poverty line and underprivileged people. This was supported by the results of data from community respondents who had received the benefits of Pure Market Operation conducted by DISPERINDAG DIY regarding the Pure Market Operation distribution target that $90 \%$ or 27 of 30 people knew that those who could participate in the Pure Market Operation program were people in the poverty line.

This finding is inn line with Al-Qaradhawi's point of view that it goes along the justice values regarding a balance between the potential of individuals both morally and materially. Holy Quran Suraah Al Hujurat verse 9 explained that Allah ask His servants to do justice. Allah Himself loves those who applied it. It implies the need to be fair to others. Ideal justice is justice without tyranny towards anyone in it. Everyone has the right to obtain rights and carry out obligations included in the distribution of income and wealth.

Regarding the speed of distribution, DISPERINDAG DIY conducted one or two Pure Market Operation activities prior to big holidays such as Christmas and Eid al-Fitr. This is supported by the results of data from community respondents who had received the benefits of Pure Market Operation conducted by DISPERINDAG DIY regarding the timeli-ness of the program implementation that $70 \%$ or 21 of 30 respondents knew that Pure Market Operation activities carried out by the government were timely.

In the security of goods, DIY DISPERINDAG worked with goods distributors so that when there is damage before the goods are received by the com-munity, the goods can be exchanged for new items. This is supported by the results of data from com-munity respondents who had received the benefits of Pure Market Operation conducted by
DISPERINDAG DIY regarding the condition of the goods. It is known that $100 \%$ or 30 of 30 respondents were aware that goods received by the community were in good condition.

This is in accordance with Sumarni's [13] view of the function of the government as an economic actor as an equal distribution of community income. Holy Quran Suraah AdzDhariyat verse 19 explained that in every asset are rights for the poor that indirectly instruct Muslims to distribute their property to help fellow human beings to meet the needs of those in need.

\section{$F$. The role of the government in stabilization}

In creating stabilization, DISPERINDAG DIY conducted two activities, one of which was Pure Market Operation . This is supported by respondent data, that $90 \%$ or 27 of 30 participants who had participated in Pure Market Operation knew that Pure Market Operation was one of the government's ways to stabilize the price of goods, whereas $10 \%$ or 3 of the 30 participants did not know that Market Operations were the government's way of stabilizing the price of goods.

This finding is in line with Sumarni [13] who explained that one of the roles of government in the economic sector is to create stability. One effort to stabilize the price of goods for the society is the implementation of Pure Market Operation. Stabilization is an action taken to prevent the occurrence of price surges that can disturb the society after doing efforts to monitor and evaluate price [3].

Price stabilization carried out by DISPERINDAG DIY through the Pure Market Operation program is in the form of pricing. Commodity goods applied are below market prices so that people in need can still consume these commodity goods with the aim of creating price stability and reducing inflation. This is supported by the results of data from community respondents who had received the benefits of Pure Market Operation conducted by DISPERINDAG DIY regarding the need for pric-ing, that $100 \%$ or 30 of 30 respondents agreed that there was a need for pricing by the government to create price stability, and regarding the accuracy of prices it is known that $100 \%$ or 30 out of 30 respondents agreed on the price offered by the government in the Pure Market Operation activities.

In accordance with Al-Qaradhawi [14], achieving price stability by means of setting a price and price agreement that the stability of a price was influenced by pricing. Furthermore, Al-Qaradhawi stated that if the pricing is intended to cause justice for the entire community, such as the pricing below the official price, then this is permitted and must be applied to create the good of society. In this case the government must set the price so that the merchant sells at a price that is suitable for the creation of justice as requested by Allah.

Pure Market Operations is a government policy to stabilize the prices of commodity goods by cutting the prices by around $10-15 \%$ below market prices [15-17]. This is supported by the results of data from community respondents who had received the benefits of Pure Market Operation conducted by DISPERINDAG DIY regarding price quotes from the government that $53.33 \%$ or 16 of the 30 majority respondents knew if the price of eggs in the market reached Rp. 23,000 then the price of eggs in Pure Market Operation activities reached Rp. 17,000. Regarding the price difference, it is 
known that $76.66 \%$ or 23 out of 30 were aware that the price difference at the time of the Pure Market Operation was between Rp. 3,000 to Rp. 6,000.

\section{CONCLUSIONS}

The application of the government's role carried out by DISPERINDAG DIY is in accordance with the three roles of the government in the view of Islam, which are as supervisors of the main driving force of the economy, as a stopper of muamalah which is for-bidden and as a price fixer. In the allocation of goods, Distribution and Stabilization that has been carried out by DISPERINDAG DIY is in accordance with the three roles of the government as economic actors.

Price stabilization according to the perspective of Islamic Economy applied by DISPERINDAG DIY in Pure Market Operation and other commodities is in accordance with the pricing and price agreement by Al-Qaradhawi. In applying the price at the Pure Market Operation, DIS-PERINDAG DIY is in accordance with the concept of Market Operation prices in general, which is price cuts between $10 \%-15 \%$.

\section{REFERENCES}

[1] I. Hidayatullah, "Peran Pemerintah di Bidang Perekonomian dalam Islam", Dinar: Jurnal Ekonomi dan Keuangan Islam, vol. 1, no. 2, 78-89, Jan. 2015. doi: 10.21107/dinar.v2i1.2691

[2] M. Munir, "Peran Pemerintah dalam Perekonomian dalam Perspektif Islam", Iqtishoduna: Jurnal Ekonomi dan Bisnis Islam, vol. 3, no. 2, pp. 1-22, 2006. doi: 10.18860/iq.v1i3.206

[3] Maisyaroh, A. Pratiwi, M. Hisjam, \& W. Sutopo, "Model Penentuan Operasi Pasar untuk Mendukung Stabilisasi Harga Minyak Goreng Curah: Studi Kasus, Spektrum Industri, vol. 15, no. 2, pp. 151-167, 2017. doi: 10.12928/si.v15i2.7548

[4] F.H. Wulandari, "Pengaruh Pertumbuhan Ekonomi, Inflasi, Pengangguran dan Pendidikan terhadap Kemiskinan Provinsi di Indonesia Tahun 2008-2012", Undergraduate thesis, Faculty of Economics, Universitas Atma Jaya Yogyakarta, Yogyakarta, Indonesia, 2012. Available: http://e-journal.uajy.ac.id/8931/

[5] W. Kurniawan, "Tinjauan Hukum Islam Terhadap Intervensi Pemerintah dalam Stabilisasi Harga", Undergraduate thesis, Faculty of Sharia and Law, Universitas Islam Negeri Sunan Kalijaga, Yogyakarta,
Indonesia, 2010. Available: http://digilib.uinsuka.ac.id/5279/

[6] D. Susilo, "Dampak Operasi Pasar Modern Terhadap Pendapatan Pedagang Pasar Tradisional di Kota Pekalongan", Pena Jurnal Ilmu Pengetahuan dan Teknologi, vol. 20, no. 1, pp. 29-37, 2011. doi:10.31941/jurnalpena.v20i1.27

[7] R. Kusumaningrum, Harianto, \& B.M. Sinaga, "Dampak Kebijakan Harga Dasar Pembelian Pemerintah Terhadap Penawaran dan Permintaan Beras di Indonesia. Forum Pascasarjana, vol. 33, no. 4, pp. 229-235, Oct. 2010.

[8] D. S. Tatuh, T. M. Katiandagho, L. W. T. Sondak, \& L. R. Rengkung, "Analisis Pengelolaan Persediaan Beras di PT. Semarak Kota Bitung”, COCOS, vol. 6, no. 8, 2015. Available: https://ejournal.unsrat.ac.id/index.php/cocos/article/vie w/8114

[9] A. Zulham \& M. Ferizal, "Kebijakan Operasi Pasar dan Pasar Beras di Nanggroe Aceh Darussalam", SOCA Jurnal Sosial Ekonomi Pertanian, vol. 7, no. 2, pp. 1-14, Jul. $2007 . \quad$ Available: https://ojs.unud.ac.id/index.php/soca/article/view/4178

[10] D. Y. Rahmasuciana, D. H. Mulyo, \& Masyhuri, "”, Agro Ekonomi, vol. 26, no. 2, pp. 129-138, 2015. doi: 10.22146/agroekonomi.17266

[11] I. Solikhin, "Wilayah Hisbah dalam Tinjauan Historis Pemerintahan Islam", Ibda' Jurnal Studi Islam dan Budaya, vol. 3, no. 1, pp. 33-44., Jan-Jun 2005.

[12] Mariadi, "Lembaga Wilayatul Hisbah Dalam Tinjauan Undang-Undang Pemerintahan Aceh", LE $\bar{E} A L I T E$ : Jurnal Perundang Undangan dan Hukum Pidana Islam, vol. 3, no. 1, Jan-Jun. 2018.

[13] Sumarni, ""Intervensi Pemerintah" Antara Kebutuhan dan Penolakan di Bidang Ekonomi", Economica : Research of Economic and Economic Education, vol. 1, no. 3, pp. 183-194, 2013. doi: 10.22202/economica.2013.v1.i2.118

[14] Y. Al-Qaradhawi, Economic security in Islam, Chicago, IL, US: Kazi Publications, Jan. 1991.

[15] R. Hessie, "Analisis Produksi dan Konsumsi Beras Dalam Negeri serta Implikasinya terhadap Swasembada Beras di Indonesia", Undergraduate thesis, Faculty of Economics and Management, IPB University. Available: https://repository.ipb.ac.id/handle/123456789/14198

[16] L. Sanny, "Analisis Produksi Beras di Indonesia", Binus Business Review, vol. 1, no. 1, pp. 245-251, May 2010.

[17] Y. Namira, I. A. Nuhung, \& M. Najamuddin, "Analisis Faktor-faktor yang Mempengaruhi Impor' Beras di Indonesia", Jurnal Agribisnis, vol. 11, no. 6, pp. 183201, Dec. 2017. 